
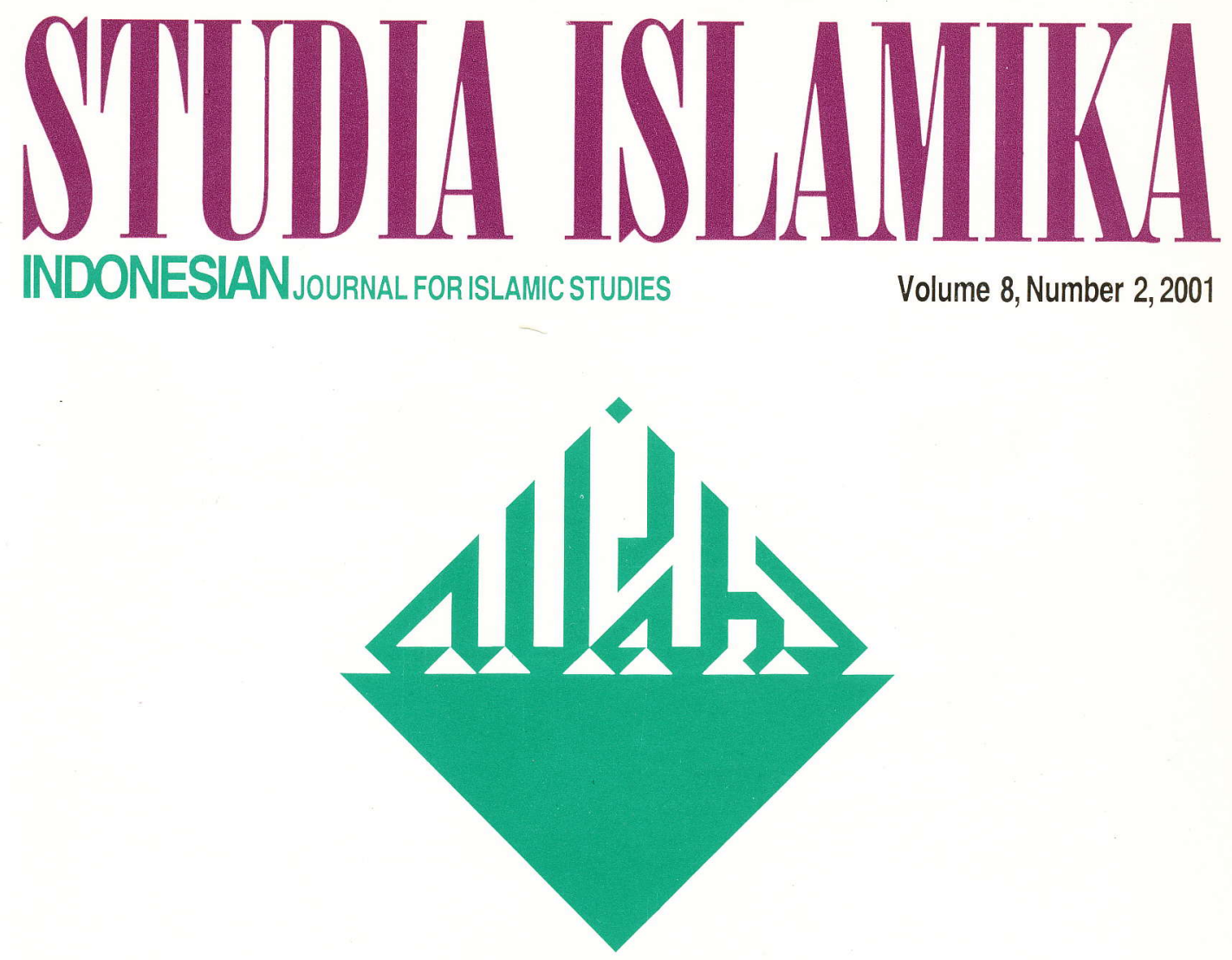

\title{
The Making of Islamic Political Tradition IN THE MALAY WORLD Jajat Burhanudin
}

SHATṬÂRIYYAH TRADITION IN WEST JAVA:

the Case of PamiJahan

Tommy Christomy

Networks of the Ulama in the Haramayn:

Connections in the Indian Ocean Region Azyumardi Azra 


\section{STIIDII ISLAIIIKL}

Indonesian Journal for Islamic Studies

Vol. 8, no. 2, 2001

EDITORIAL BOARD:

M. Quraish Shihab (IAIN Jakarta)

Taufik Abdullah (LIPI Jakarta)

Nur A. Fadhil Lubis (IAIN Sumatra Utara)

M.C. Ricklefs (Melbourne University)

Martin van Bruinessen (Utrecht University)

John R. Bowen (Washington University, St. Louis)

M. Atho Mudzhar (IAIN Yogyakarta)

M. Kamal Hasan (International Islamic Unizersity, Kuala Lumpur)

\section{EDITOR-IN-CHIEF}

Azyumardi Azra

\section{EDITORS}

SaifulMujani

Jamhari

Jajat Burhanuddin

Fu'ad Jabali

Oman Fathurahman

\section{ASSISTANT TO THE EDITORS}

Heni Nuroni

ENGLISH LANGUAGE ADVISOR

Chloe J. Olliver

\section{ARABIC LANGUAGE ADVISORS}

Nursamad

Husni Thamrin

\section{COVER DESIGNER}

\section{S. Prinka}

STUDIA ISLAMIKA (ISSN 0215-0492) is a journal published by the Center for the Study of Islam and Society (PPIM), IAIN Syarif Hidayatullah, Jakarta (STT DEPPEN No. 129/SK/DITJEN/PPG/STT/1976) and sponsored by the Department of Religious Affairs of the Republic of Indonesia. It specializes in Indonesian Islamic studies, and is intended to communicate original researches and current issues on the subject. This journal warmly welcomes contributions from scholars of related disciplines.

All articles published do not necessarily represent the views of the journal, or other institutions to which it is affiliated. They are solely the views of the authors. The articles contained in this journal have been refereed by the Board of Editors.

STUDIA ISLAMIKA has been accredited by The Ministry of National Education, Republic of Indonesia as an academic journal. 


\section{Shațâriyyah Tradition in West Java: the Case of Pamijahan}

Abstraksi: Tradisi mistis Islam (tasawuf) tidak hanya mengekspresikan aspek ritual keagamaan belaka, tapi lebih dari itu juga dapat mencerminkan pola-pola perilaku sosial masyarakat penganutnya. Sebagai sebuah perilaku sosial, tasawuf tentu saja banyak bersentuban dengan berbagai tradisi lokal, sehingga pada gilirannya melabirkan beragam artikulasi yang menjadi bagian tak terpisabkan dari masyarakatnya.

Salab satu bentuk artikulasi paling nyata dari persentuban tasawuf dengan tradisi lokal adalah tarekat. Dalam tradisi Islam, institusi tarekat senantiasa berkembang sejalan dengan konteks sosial-politik dan budaya masyarakat Muslim. Maju mundurnya sebuab tarekat berbubungan erat dengan pola bubungan sosial yang terjalin dengan anggota masyarakat. Dalam konteks terakhir inilah, silsilah (intellectual genealogy) menjadi sangat penting bagi keberadaan suatu tarekat. Silsilah memberikan legitimasi keagamaan bagi suatu tarekat, karena ia menghubungkan guru sufi di tarekat dengan mazhab sufi tertentu di dunia Islam. Dengan demikian, melalui silisilah, legitimasi dan otentisitas sebuab tarekat -kbususnya dari sudut pandang keagamaan-bisa terjamin, sebingga tarekat tersebut bisa dengan mudab memperoleh pengikut yang besar dari masyarakat Muslim. Jika dianalogikan, signifikasi silsilab dalam tarekat ini dapat dianggap paralel dengan peranan krusial isnad dalam tradisi hadis.

Dalam tradisi yang disebut terakbir ini, otentisitas dan validitas sebuah hadis sangat ditentukan oleb urutan para perawinya; apakab mereka terbubungkan dengan baik sampai pada Nabi Mubammad (mutawattir), atau putus di tengah jalan. Demikian halnya dengan silsilah dalam tradisi tarekat;jika seorang ulama sufi dibubungkan melalui mata rantai silsilab 
dengan para guru pendiri tarekat tersebut, maka dapat dipastikan ia akan mendapat legitimasi yang besar dari para pengikutnya, sehingga memudabkan bagi dirinya untuk mensosialisasikan berbagai ajaran dan pemikirannya.

Artikel ini mendiskusikan signifikasi silsilah dalam tradisi tarekat dengan mengambil contob tarekat Shatariyyah yang berkembang di Pamijahan, Jawa Barat. Fokus utama pembahasan mencakup setidaknya tiga hal penting: pertama, mencoba merekonstruksi silsilah tarekat Shatariyyah di Jawa Barat, khususnya Pamijahan, mulai dari tokoh utamanya, Shaikh Abdul Mubyi, hingga murid-murid masa kemudian; kedua, berusaha menghubungkan tradisi lokal tarekat Shatariyyah di Pamijahan dengan tradisi besar tarekat tersebut di wilayah Melayu-Indonesia kbususnya, dan di dunia Muslim pada umumnya; dan ketiga, berusaha melihat implikasi tradisi tarekat Shatariyyah terhadap perilaku sosial-keagamaan para pengikut dan masyarakat sekitarnya.

Figur Shaikh Abdul Mubyi sendiri dalam artikel ini digambarkan sebagai seorang ulama sufi yang terbubungkan silsilab tarekatnya dengan para ulama sufi Melayu-Indonesia terkemuka, 'Abd al-Râ̂f al-Sinkîlî. Hubungan guru-murid antara al-Sinkîlî dengan Abdul Mubyi menjadi sangat penting, terutama dalam konteks persebaran tarekat Shatariyyah ke wilayah Jawa, termasuk Pamijahan di Jawa Barat. Dengan "menyandang" legitimasi dari al-Sinkîlî inilah, Shaikh Abdul Mubyi berhasil membangun jaringan keilmuan yang lebih luas. Hal ini antara lain terlihat dari banyaknya silsilah tarekat di Jawa Barat melalui dirinya, yang kemudian terbubungkan hingga ke al-Sinkîli. Kondisi tersebut pada gilirannya menciptakan sebuah komunitas intelektual yang berperan penting dalam proses perkembangan Islam di Indonesia, khususnya Jawa Barat.

Di Pamijahan misalnya, Abdul Mubyi -yang juga mempunyai bubungan guru murid dengan Shaikh Yûsuf al-Makassarî-memainkan peranan penting dalam mengubah kepercayaan masyarakat setempat dari animisme menjadi Islam. Peran penting yang dimainkan Abdul Mubyi di Pamijahan, dan kemudian dilanjutkan murid-muridnya, menjadikan dirinya seorang sufi sekaligus wali, yang diyakini masyarakat setempat sebagai mendatangkan barakah (the blessing), dan secara tidak langsung mensejabterakan tarafkehidupan ekonomi mereka. Oleb karena itu, bagi masyarakat Pamijahan, menghubungkan silsilab diri dan keluarga mereka dengan Shaikh Abdul Mubyi bukanlah semata menjadi terma tasareuf, tapi lebih dari itu adalab merupakan identitas diri yang sangat dibanggakan. 
Shatțâriyyah Tradition in West Java:

the Case of Pamijahan

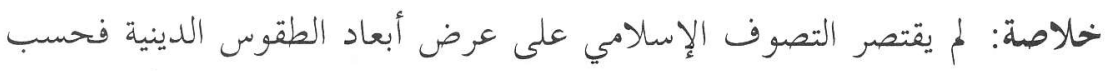

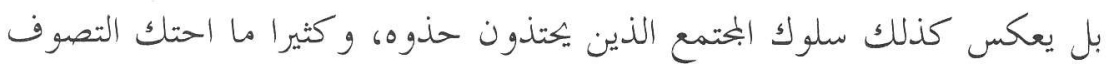

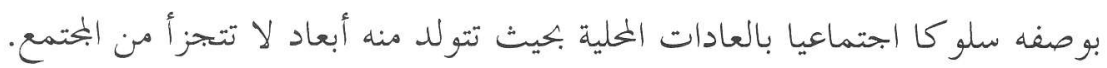

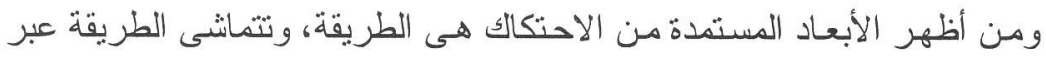

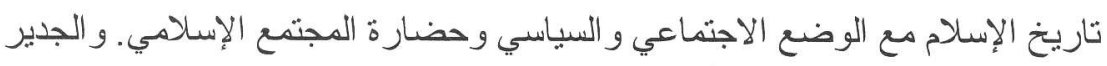

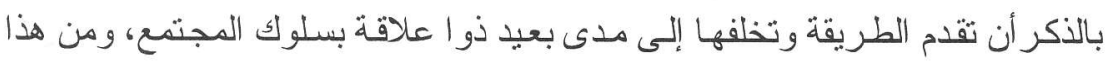

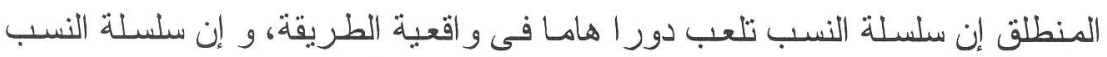

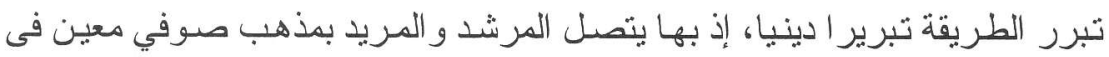

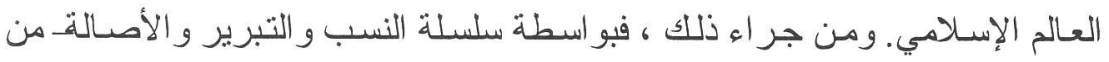
النظرة الدينية بخاصة أصبحت الطريقة معتبرة، ونتيجة لذلك أن يكثر أتباع الطريقة

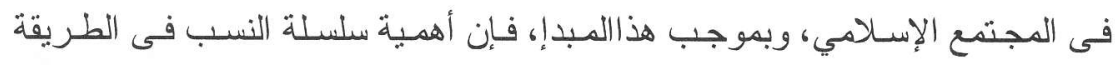

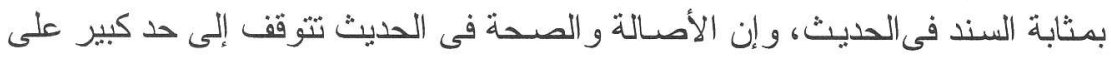

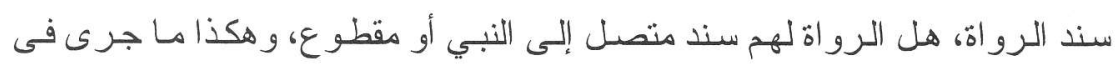


الطريقة، إذا اتصلت سلسلة علم صوفي بمنشئ إحدى الطريقات فله تبرير من أتباعه ويثزنب على ذلأك أن سهل عليه تعمبم تعاليمه و أفكاره. ويعالج هذا البحث سلسلة النسب في عرف الطريقة باتخاذ الطريقة الثـاطرية بياميجاهان (Pamijahan) بجاوى الغربية در اسـة الحالة، وهو بعالج على الأقل ثلاث

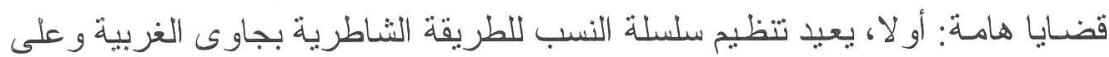
ر أسها باميجاهان من عدها الرئيسي الثيخ عبد المحي إلى مريديه؛ وثانيا، يحاول

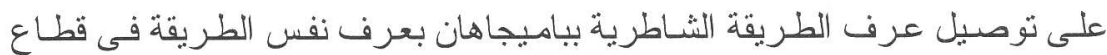
ملايو- إندونيسيا خاصـة وفى العـالم الإسـالامي عامـة؛ وثالثنا، بعدل على النظر إلى لى ممارسة عرف الطريقة الثاطرية فى سلوك المجتمع الديني من أنباعه و المجتمع حول الأتباع.

ويصف هذا البحث شخصية الثيخ عبد المحي كالعـالم الصـوفي الذي تتصل طريقته بالعالم الصوفي بملايو- إندونيسبا الثهير عبد الرؤوف السنكيلي، و أصبحت

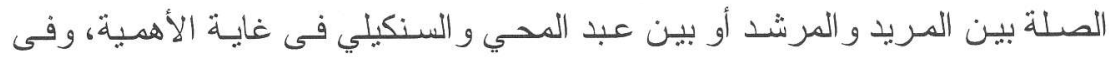
مقدمنها فى نشر الطريقة الثـاطرية بجزيرة جاوى وهن ضدنها باميجاهان بجاوى الغربية، وبموجب هذه الصلة كان الثيخ عبد المحي نجـح في بناء الصلة العلدية الو انسعة، ويبدو ذلك جليا فى و اقعية كثرة سلسلة الطريقة بجاوى الغربية المنصلة به و المتصلة بوسـاطنه بالسنكيلي. وشكل هذا الوضع في دور هجتمعا عقلا نيا ذا دور حيوي فى نطور الإسلام بإندونبسيا و على ر أسها بجاوى الغربية. وهنال ذلك مـا حدث ببامبجاهان من أن للشيخ عبد المحي دور ا هامسا في تغيير عقيدة المجنمع المحلي من الأرو احبة (الاعتقاد بأن لكل مـا فى الكون وحتى للكون ذاته روحا أو نفسا) إلى العقيدة الإسلامية، ورتب الدور الذي لعبه عبد المحي و الذى

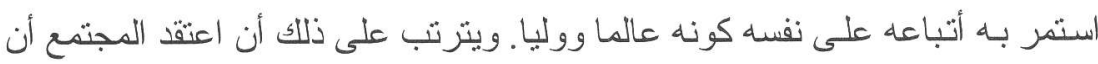
البركة ورفاهية الدعاش جائت به، ومن أجل ذلك ، إن نوصبل النفس و الأهل للمجتمع باميجاهان بالثيخ عبد الهحي لا يتو قف على النطاق الصـوفي بلـ بمتـ إلى أن ذلك هوية ذاتية مفتخرة. 
ufism is an Islamic mystical tradition which expresses not only ascetic rituals but also model of social practices. As a social practice, Sufism has an intensive contact with other different traditions, which then creates various impacts on its articulation. This condition can be seen for instance in the courses of sufi order (tarekat), where various divergent modes of development becomes its salient features. Some of sufi orders for examples have to modify their teaching and organization in order to be able to gain new followers and political support from the authority, while the others lost their followers because they fail to reformulate the position in a changing society. One of the most important aspects to determine the courses of development of Sufi orders is silisilah (intellectual genealogy of sufi masters). This is of special significance to provide the sufi orders with a cultural legitimacy and doctrinal authenticity.

The role of silisilah is therefore parallel with that of isnâd (chain transmitters) in hadith literature. Like Sufi order, the authenticity of a hadîth can be seen from its chain transmitters going back to the Prophet Muhammad (mutawattir). Thus both silisilab in Sufi order and isnâd in hadith literature are regarded as the basis of the development of Islamic knowledge (Voll, 1980: 246-273). The silisilah of sufi orders involves some leading ulamas (Muslim scholars) in the transmission of Islamic knowledge, the sufistic knowledge, which traces back to the ulama credited as the founder of sufi order. The silsilah therefore can function as an intellectual community, which is of crucial role in the establishment of the intellectual networks especially between the Middle-eastern and Malay-Indonesian ulamas (Azra, 1995: 105).

Viewed in this perspective, it can be assumed that silislab has a major important role determining the existence of sufi order. The silsilah to some extents can also be seen as an argument and ideology, which is subscribed to by its followers, so that a sufi order can be socially accepted and religiously justified. The Shațâriyyah tradition in Pamijahan, which this artcile deals with, is a good example of the dynamics of sufi tradition in Java, which can be seen from their reception on narrative of the Sufi master (silsilah). The discussion of this artcicle will elaborate the silsilab of Shattâriyyah in Pamijahan and its implication to their followers. It is evident that until now there is no adequate information regarding Shațâriyyah tradition in West Java, particularly Pamijahan, which had been a famous centre of Shatțâriyyah in Java since its the early period. Describing this is- 
sue, it is hoped that article can come to the description of general background of Shațâriyyah tradition in Indonesia.

\section{Pamijahan: The Sufi Village}

"This village had formerly been a wild forest. No one lived here. Then came 'animist' (sundanese: urang Hindu). They performed witchcraft. Our holly man (wali) finally came here and defeated Batara Karang, orang Hindu. This place then became prosperous. Pilgrims come here without being invited because of the blessing of the holy men radiating from this place".

The above quotation, recited by an ordinary man as he was chatting with some pilgrims in a cafe stall, reveals three important key words representing three important periods of Pamijahan: 'the wild forest', 'the animist', and 'the wali'. A climax of the narrative falls on the third episode where the wali introduced Islam and grace to the people. He is described as a protagonist who was able to clean the land of the wild and gave moral foundation and identity for the villagers. This episode is related to the conversion of Pamijahan people by Sufis in $17^{\text {th }}$ century. The villagers, accordingly, are very proud to be descendants of the Sufi saints. They established a family cult, and were able to extend their family cult as part of the popular tradition called ziarah (pilgrimage to a holy man's gravesite).

According to a custodian, some time in the 1660's, a wali (holy man) from Mataram in his sacred travelling cleared away some bush in a wild forest in the Southern area of West Java. On the way, the wali, who came to be known with the name Shaykh Abdul Muhyi, fought with a local animist ruler known as Batara Karang. The Batara Karang surrendered to the wali and converted to Islam. He then continued his mission to find a sacred cave for meditation as suggested by his guru (teacher). After trekking through the forest, he found the cave in a hilly area. He called this place Safarwadi. Custodians say that the term Safarwadi1 or 'walking in the valley' has metaphorical meaning; namely, that a human being should follow the right path as if traversing a muddy sloping riverbank. If he takes a wrong step, he will slide into deep misery. Later, particularly after Shaykh Abdul Muhyi died, people began to call this village by the name of its river, Pamijahan. Pamijahan, according to them, means a natural place for fish hatching (lauk mijah) ${ }^{2}$. After the wali settled in this Valley, his fame was such that his followers swarmed to the valley like hatching fish. 
From the above explanation, what is important to ascertain is the fact that Pamijahan people signify their historical past in relation with Sufi figure, Shaikh Abdul Muhyi. As the above quotation suggests, the coming of Shaikh Abdul Muhyi is credited as the turning point in the history of Pamijahan people; that his time coming is the beginning of "the new age" of Pamijahan, both in term of religion and social-economics. The people converted to Islam, and the area became well known as a sufi village radiating the blessing (baraka) to the people coming for visiting the holly sufi tomb (ziarab). Therefore, almost all Pamijahan people claim to be descendants of Shaykh Abdul Muhyi, the holly Sufi. They have translated this claim for instance into spatial space, which makes them slightly different to the rest of the people of Tasikmalaya.

In contemporary terms, Pamijaban refers to two different concepts. The first is a cultural concept, which associate Pamijahan referring to the area believed physically to be the place of various important artifacts (patilasan) and narratives of the wali. Pamijahan in this sense covers the valley of Pamijahan and the surrounding mountains as stated by one of the old custodians. The second is a modern political concept. In this case, Pamijahan refers to a 'kelurahan', the smallest political unit of the Indonesian government. This area consists of various sub villages (kampung). The villagers themselves use Pamijahan for the first concept and Desa Pamijahan for the second. Desa Pamijahan is led by a village head (Kepala Desa), while Pamijahan is led by the Custodian (Kuncen).

Desa Pamijahan belongs to the southern part of the regency (kabupaten) of Tasikmalaya in West Java. Tasikmalaya, who has 800 registered traditional Islamic boarding school (pesantren), has been touched by various Islamic movements until now. Tasikmalaya is known as an area touched by Islamic rebellion in the $17^{\text {th }}$ century promoted by the followers of Bantenese and Macassarese who retreated there from the north coast. In 1945, there was rebellion instigated by the Ajengan ${ }^{3}$ of Sukamanah where hundreds unarmed young Muslims were killed by the Japanese. Later, between 1956 and 1962 Tasikmalaya was used by the most famous Islamic rebels called the Tentara Islam Indonesia or TII (Islamic Army of Indonesia). Led by Kartosuwiryo, a Javanese who gained lot of support from the elite Sundanese in the remote area of West Java, the rebel promoted the establishment of Islamic state, Darul Islam.

As in other districts of Tasikmalaya, statistics on religious affilia- 
tion show clearly that Pamijahan is one hundred percent Muslim. Kabupaten Tasikmalaya is known as a major religious center in West Java after Cirebon and Banten. Statistics on membership bear this out. According to data from Department of Religion of Tasikmalaya, in 1996 there were 800 registered Islamic traditional boarding schools (pesantren) scattered around its villages. In general, these pesantren are affiliated to Nahdlatul Ulama $(\mathrm{NU})^{4}$, the traditionalists.

Only a few pesantren (traditional boarding scholl) belong to Muhammadiyah ${ }^{5}$ and Persis ${ }^{6}$, the modernists, who are mainly situated in the city of Tasikmalaya. Pesantren Cipasung is the biggest of NU's traditional boarding school in Priangan Timur. There are also pesantren, which focus on Sufism. Pesantren Suralaya, for example, about hundred kilometers to the north of Pamijahan, is the best known Sufi pesantren in Tasikmalaya and is also known internationally as a center of the Sufi Order of the Qadiriyah wa Naqshbandiyah ${ }^{7}$. Another is Pesantren Pagendingan, which follows the Idrîsiyah Or$\operatorname{der}^{8}$.

Villagers from Desa Pamijahan are recorded in the Village Office (Kantor Bale Desa) as farmers, peddlers, laborers (burub), and members of the military. However, it is difficult to rely on such statistics in reality. Although the villagers may have paddy fields, they do not claim to be farmers. They prefer to identify themselves by a job which is not associated with farming activities. According to them, to call your self a true farmer (patani) you should have a larger amount of land than have. They also argue that they rarely go to their paddy field as farmers because they always hire laborers to cultivate their lands. This claim is partly due to their activities associated with pilgrimage (ziarab). Men in Pamijahan and Panyalahan, for example, quite often are involved in the guidance of pilgrims to sacred sites where they can earn money for daily needs, while women help their husbands by selling gifts to the pilgrims. During my fieldwork, I hardly ever found women who went to the fields to cultivate their lands. This contrasts with other villages where women have to care for their own gardens (kebun). Instead of cultivating their gardens, the women of this village prefer to buy fresh produce from people who come from neighboring areas, particularly in busy months such as Maulid or Rajab when pilgrims come in thousands each day. In such setting, the family of the wali try to perpetuate Shattâriyyah Order. 


\section{The Root of Shattâniyyah}

The pilgrims from Mecca brought the international character of the Islamic world into Malay-Archipelago.' Shațâriyyah teaching in its early period also reflected such an influence. In this stage, particularly in Sumatra, the Mecca masters dominated the interpretation of all Islamic teachings, including that of Sufism. The most popular case was the influence of al-Qushâsî and Ibrâhîm al-Kûrânî on their Indonesian pupils in the $17^{\text {th }}$ century. However, in other areas such as Java, Sufism underwent various directional changes. The transmission seems more complicated because the Javanese were more interested in practical than theoretical interpretations. For example, some followers in Eastern Java believe that Shațâriyyah order provides a means to control spiritual power. In some places in West Java, there are some martial arts and alternative healing centers associated with the master of the Shațâriyyah.

It is important here to recall Rinkes' (1909) finding about the nature of Shattâriyyah linked to 'Abd al-Ra'ûf. Part of Rinkes' dissertation examines the foundation of the Shatțâriyyah's metaphysical doctrine called the Seven Levels of Being in Java (martabat tujub). Rinkes found the Javanese Shațâriyyah consisted of general characteristics as well as elements from other parts of the world. He made the following points about the Javanese version: (a) disregarding inaccuracies on the writer's part, the Javanese language, like most other languages, does not lend itself to an exact rendering of notions in another language, even if the author intended to render them in his own words; (b) the writing, without being a direct imitation or version of a foreign original, does not express the pure Javanese thought of the writers, but only indicates which ideas are notions they absorbed and which ideas influenced their pupils; (c) because of the religious sentiments of the Javanese, generally lacking in a lively exchange of thought, one should not expect to find sharply outlined dogmas and can expect even less in their mystical speculations. Rinkes tends to assume that the leading notions in the field of Sufism have not been incorporated into a complete system.

Although Rinkes's study has contributed much to our understanding of the development of the Shatțâriyyah in Java, in some respects Rinkes did not pay attention to local practices, particularly those of Pamijahan, where the Shațâriyyah was first introduced. This is reflected in the manuscripts he used. Rinkes consulted, for example, the Cirebon manuscripts rather than manuscripts available in Pamijahan 
itself, which he visited in 1909. Now some important Shattâriyyah manuscripts from Cirebon present different genealogies (silsilab) to the mss. of Pamijahan. The Shattâriyyah Order in Cirebon, particularly as practiced in the court, is more exclusive. Rinkes also does not inform us whether these manuscripts available in the village were still in use in mystical circles in Pamijahan. These observations remind us that the history of Sufism in Java is still far from clear. Nevertheless, we still need more elaboration regarding the nature of Sufism in places that in previous times appeared as significant centers such as Pamijahan.

About these phenomena, it is important to describe the silsilah Shattâriyyah in contemporary Pamijahan, particularly given that the villagers have transformed Pamijahan into one of the most famous pilgrimage sites in Java. The master of Shattâriyyah, Shaykh Abdul Muhyi, is not only recognized as a Sufi but also as a saint who radiates baraka to those who come to Pamijahan after his death.

Recent studies mention that the silsilah is part of the intellectual network linking various scholars from different places in Indonesia (Azra 1992). In his important historical study, Azra draws various interrelated figures influenced by the idea of Neo-sufism. ${ }^{10}$ According to Azra, Neo-sufism is an effort to reconcile mysticism, or tasawewnf and law, or sharîah. The Silsilah Shattâriyyah, particularly in Indonesia, is part of this process. Azra's work is very important because he uses extensive primary sources written by the figures in the networks being studied. Nowadays, in several places in Java, including Pamijahan, the order has been overwhelmed by other orders and has lost followers. Muhaimin argues that the decline of Shattâriyyah in Cirebon is partly due to its complicated teaching (Muhaimin 1995). Other taríqah such as the Tijâniyyah, for example, have gained much popularity for having simpler doctrines. Pamijahan stands out as an exception. Even though the Shattâriyyah is facing problems as in other places in Java, villagers in Pamijahan who claim a close genealogical connection with its master are trying to perpetuate this tradition. A routine Shattâriyyah congregation is held weekly in a villager's house.

\section{The Shattâriyyah Order in the World of Islam}

Shattâriyyah tradition is influenced heavily by Transoxiana's tradition, however in time this tradition were also influenced by Indian and Arabic tradition (Trimingham, 1998:41). Furthermore, this tradition has been 'domisticated' in order to match with the local needs. Shattâriyyah sislilah to some extent represents such dynamic. 
The Shattâriyyah silsilab is linked to Abû Yazîd al-'Ishqiyyah of Transoxiana, who was influenced by Imâm Ja'far al-Ṣadiq (d. 146/ 763) and Abû Yazîd al-Bastâmî (d. 260/874). (These two figures appear in the silsilah as the eighteenth and the nineteenth predecessors of Shaykh Abdul Muhyi.) Abû Yazîd al-'Ishqiyyah's order was known as the 'Ishqiyyah in Iran and the Bistâmiyyah in Otoman Turkey (Trimingham, 1998:41). The 'Ishqiyyah was popular in $5^{\text {th }}$ century Central Asia. After the Naqshabandiyyah order received more attention in the same area, the 'Ishqiyyah's popularity decreased (Trimingham, 1998:41). One of his successors, Shâh 'Abd Allâh (d. 1428-9) (who appears in the genealogy of Pamijahan manuscripts as the ninth master before Shaykh Abdul Muhyi) brought the order to more prosperous soil for his teachings, namely India. In this place, Shâh 'Abdullâh was associated with the Shattâtriyyah, which had become another name for 'Ishqiyyah (Rizvi 1983).

After 'Abd Allâh al-Shațar, the Shațâriyyah was led by Shaykh Hidâyat Allâh Sarmat (the eighth predecessor), and Shaykh Hâjji udârî (the seventh predecessor). The most important of 'Abd Allâh al-Shattar's successors was the famous Muhammad Gawth of Gwalior (d. 1562-3). According to Rizvi (Rizvi 1983), he extended the popularity of the Shattâriyyah among the locals by retranslating Yogi's manuscript, the Amtritkunda and adapting its practices into Shattâriyyah dhikr formulae. He was also known as a Sufi who respected followers of Hinduism. Furthermore, he was a prolific writer of numerous mystical works. During his period the doctrine of the Shattâriyyah was codified and strengthened, as may be seen in his work Jawâhir al-Khamsah (The Five Jewels/Precious Things). Such phenomena affirm that the Shațâriyyah in India was mainly influenced by the role of its Shaykh, actively propagating his teachings. Another factor, which stimulated Shațâriyyah tradition, was that its leaders were able to cooperate with the courts, as seen in the period of the great Moghuls, Shâh Jahân and Aurangzib. Shâh Jahân and Aurangzib granted recognition to the order as one of the official orders of the empire (Rizvi 1983).

After Muhammad Gawth of Gwalior, the order was continued by Shaykh Wajh al-Dîn Gujaratî (the fifth predecessor). In India, Shaykh Wajîh al-Dîn Gujaratî (d. 1018/1609) was able to promote the Shattâriyyah order throughout the subcontinent (Rizvi, 1983:50). The method of contemplation which shows similarity with yogic practices and the eccentric behaviour of its master were the impor- 
tant factors in the Shatțâriyyah's development in India. Furthermore, through Shaykh Wajîh al-Dîn Gujaratî's successor, Sultan 'Ârifîn Sibghat Allâh b. Rûh Allâh, and Shaykh Ahmad al-Nashawî, the order spread to Mecca and Medina (Rizvi, 1983:50). In the seventeenth century these two cities emerged as sanctuaries of various Sufi orders and "became great diffusion centres". It was through this line that Ahmad Qushâshî obtained his silsilah.

Even though some scholars have classified the Shattâniyyah as a minor order in India (Rizvi 1983), in the Indonesian archipelago during the $17^{\text {th }}$ century the Shattâriyyah emerged as an important order, particularly in Sumatra. Its followers emerged as key players in local social transformation. The king of Buton, for example, adopted Shattâriyyah symbolism to impose a hierarchical society. In Ulakan, Minangkabau, the Shatțâriyyah provided rebels with a spiritual power to counter the Dutch. The same situation was also found in Java. Shaykh Abdul Muhyi, the leader of Shattâtiyyah there, provided the prominent rebel Shaykh Yusuf of Sulawesi with accommodation and political sanctuary. Abdul Muhyi's followers also took up arms against the Dutch (Kraus 1995).

\section{The Shațâriyyah Silsilab in Indonesia}

Below I will outline in general the setting of the $17^{\text {th }}$ century when the Shattâniyyah was introduced into Indonesia. In this period Sufism and the tariqah were dominated by the North Sumatran school of Hamzah Fansuri, which was attacked as pantheistic by his opponents, such as Nûr al-Dîn al-Rânîrî (see Johns, 1965).

However, both Hamzah and his opponents often quoted Ibn 'Arabî teaching regarding the nature of creation, while never being able to agree on how God manifests Himself in the world. Hamzah Fansuri's work, for instance, explains that the phenomenal world is the external manifestation (tajallî) of the Ultimate reality. From Hamzah Fansuri we read:

La ilaha ilAllah itu kesudahan kata

Tauhid marifat semata-mata

Hapuskan hendak sekalian perkara

Hamba dan Tuhan tiada berbeda (Alisjahbana 1961:76)

La ilaha ilAllah is the final word

the way to the Unity of God

forget the other matters

Servant and Lord are not different 
This poem reflects an entire system which is generally designated by the term 'The Unity of Being' (wahdat al-wujûd), comparable to Ibn al-'Arabi's conception (al-Attas 1966). In Hamzah Fansuri's view, the world is an outpouring of God's love. Borrowing Schimel word, the relation between Creator and creation are like water and ice, the same being in different modes or manifestations (Schimel 1975).

Hamzah's follower, Shams al-Dîn of Pasai (d. 1630) developed this idea; but, for the first time in Sumatran Sufi practice, he adopted the Seven Levels of Being from Tuhfah. Johns argues that the seven levels of being in the Sumatran Sufi's work are more systematic than those of his predecessor (1955: 57). The Seven Levels of Being is a cosmology, which explains the relation between the Absolute and the relative. This view resembles that of Ibn al-'Arabî that the relative is an outward manifestation of the Absolute. The main advantage of Ibn al-'Arabi's concept, which was adopted by Shațâriyyah, is that it supplies a metaphor which solves the philosophical problem of the relation between the Absolute and the relative, or the One and manyness.

However, such a solution only can and does appear on a metaphorical level. The difficulty with it for orthodoxy is that mystical expressions applying unconventional metaphors such as 'I am God', or 'Servant and Lord are not different' are simply unacceptable.

Thus, the Seven Levels of Being had to be interpreted in different ways. Sumatran Sufis, such as Shams al-Dîn al-Samatrầî, interpreted the doctrine in heterodox terms but Nûr al-Dîn al-Rânîrî and 'Abd al-Raûf al-Singkel comprehended it in an orthodox way.

Actually, Nûr al-Dîn al-Rânîrî, like Hamzah, applies the metaphor of Light and its shadow (zill) to describe the relationship between God and His creation. According to him, this world is God's shadow ("Wujud mabkluk itu terang dan benderang yang jadi ia daripada nur wujud Allab".) (Nûr al-Dîn al-Rânîrî, Hill al-Zill: see also, Christomy 1986: 64). In this state both Hamzah and al-Rânîrî subscribe the same assumption about the reality. In their terms, the reality is the shadow of the ultimate. The big differences between them lie on their interpretation on 'shadow'. For Hamzah, the shadow is the logical consequences from the light. It is not created but reflected. On the other hand, al-Rânîrî assumes that the shadow is created by the ultimate.

In his 'catecismus' al-Rânîrî asserts that: 
Jika demikianlah ditamsilkan segala ahli sufi akan Haq Táâlâ dengan makhluk, bahwasanya wujud Haq Táâlâ itu sekali-kali tiada wujud Allah. Seperti kata jâbib al-Insân al-Kâmil...Maka jika ada engkau itu Haq Taala, maka tiada engkau itu engkau, tetapi Haq Ta'âlâ itu engkau, maka tiadalah Haq Ta'âlâ itu Haq Ta'âlâ tetapi engkau itu engkau jua. Maka nyata daripada kata ini sekali-kali wujud Haq Ta'âlâ itu tiada jadi wujud makhluk dan wujud makhluk itu sekali-kali tiada jadi wujud wujüd (Hill al-Zill: see also Christomy 1986: 64)

If the Sufi compares Haq Ta'âlâ with humans; indeed there is no parallel between wujud Haq Ta'âlâ and God. This is explained by the master of al-Insân al-Kâmil...If you have the quality of Haq Ta'âlâ you will not exist as men, but you will be Haq Ta'âlâ. Haq Ta'alâ is Haq Ta'âlâ but you are a man (not Him). The meaning of this word is that wujud Haq Ta'alâ is never embodied in mankind and mankind is not the manifestation of wujud Haq Ta'âlâ.

According to Al-Rânîrî the ultimate reality (wujud Haq Ta'âlâ) has never become manifest in mankind (wujud makhlîq) and vice versa:

Bahwasanya Hakikat Allah itu sekali-kali tiada harus dikata akan dia berpindah kepada hakikat makhluk itu dan hakikat makhluk itu sekali-kali tiada harus dikata akan dia berpindah kepada hakikat Allah

That is the Essence (Allah) never embodies in the mankind and the mankind never embodies in the Essence (Allah).

These differences often escalated into polemic and even political friction among the patrons such as the Acehnese Sultans and other supporters. The conflict between Nûr al-Dîn al-Rânîrî and Hamzah Fansuri's followers became well known in this period. Al-Rânîrî was urged by the Sultan to make a statement (fatwâ) regarding wahdat alwojî̀, which was carried out, against Hamzah and Shams al-Dîn. He tried to modify Ibn al-'Arabî's teaching to an orthodox perspective. However, al-Rânîrî's decision was perhaps more political than mystical. In fact, he was the appropriate figure to support the palace policies, which followed orthodox tradition. For instance, he suggested that all old manuscripts, which did not carry at their head the habitual formulaic opening of Islam, should be burned. He also persuaded the Sultan to ban the wahdat al-wujûd's teaching. However, after his royal patron died, al-Rânîrî struck political difficulties. The next Sultan (years) held views different to those of al-Rânîrî and as a consequence, al-Rânîrî's position deteriorated. He fled back to Gujarat. The more moderate qậ̂h, 'Abd al-Raûf al-Singkel was assigned in his place.

Those responsible for a domestication of Ibn 'Arabî's teaching are 
the Meccan masters, al-Qushâshî and al-Kurânî and their pupil, 'Abd al-Raûf Singkel. Al-Qushâshî was a famous as a leader of Jawi students in the $17^{\text {th }}$ century. He had links with various mystical orders, but in Indonesia, he was best known as the Shattâriyyah master. $\mathrm{He}$ obtained his Shațâniyyah silsilah from Sibghat Allâh's pupil, 'Abd alMawâhib al-Shinnâwî. Sibghat Allâh was a close friend of the writer of Tuhfah, Muhammad Ibn Fadl Allâh al-Burhânpûrî. Both appear as students of the popular master of Shattâriyyah Wajîh al-Dîn al-'Alawî, who in turn was a student of Muhammad Ibn Khațir al-Dîn of Gwalior. Al-Qushâshî deliberately chose to teach Shațâniyyah mysticism to his Jawi students. Through his disciples the metaphysical doctrines of the Martabat were transmitted to Indonesia as part of orthodoxy and became the trademark of Shattâriyyah.

Among al-Qushâshî's students was 'Abd al-Raûf al-Singkel, who in turn was a master to Shaykh Abdul Muhyi of Safarwadi. 'Abd alRaûf differed in several respects from his colleagues. He did not condemn his predecessors as heretical (kâfir billab), as al-Rânîrî had not hesitated to do. 'Abd al-Raûf's response to the polemic between alRânîrî and Hamzah's followers was moderate. He probably was not obliged to make a statement (fatwâ) regarding Hamzah teaching for the court, because according to him a Moslem does not have an obligation to condemn other Moslems as Kâfir. "It is dangerous to accuse another of kufr. If you do so and it is true, why waste words on it, and if it is not true, the accusation will turn back upon yourself" (Johns, 1955:60). It must be taken into account, however, that these tendencies occurred as part of a general shift in the archipelago in the $17^{\text {th }}$ century for legalists and mystics to be reconciled.

In sum, $17^{\text {th }}$ century Indonesia was characterised by various mystical contests as the result of international infusions of the tariqah brought back by returned pilgrims. The emergence and decline of a certain order was much influenced, for example, by the fluctuating fortunes of its tariqah in Mecca. In this period, there was a great tendency to combine Sufism with Sharîah. Thus, the attempt was made for every pantheistic element in tarîqah, including Shattâriyyah, to be reshaped in accordance with more orthodox features.

\section{The Shațâriyyah Silsilab in West Java}

It is evidence that the Shatțâriyyah silsilah in Java follows two main lines. The first can be traced back to the Cirebon. According to Muhaimin, The Cirebon chain refers to: "Shaykh Ahmad bin Qaras 
al-Sanawî (Muhaimin 1995). He was the father of al-Qushâshî who taught Abdul Muhyi's teacher. Shaykh Ahmad Qaras al-Sanawî, in turn, taught Shaykh 'Âlam al-Rabbânî, who, in turn, taught Shaykh Hatib Qabat al-Islam who, in turn, taught Shaykh 'Abd al-Waqâb who, in turn, taught Shaykh Imam Tarbiyi, who, in turn, taught Tuan Shaykh 'Abd Allâh bin 'Abd al-Qahhâr, who, in turn, taught Tuan Hajji Muhammadin Mu'tasin, who, in turn, taught Shaykh Imam Qâdir Îmân Hidâyat bin Yahyâ who, in turn, taught Sayyid Shaykh Muhammad Arifudin who, in turn, taught Raden Muhammad Nûr Allâh Habîb al-Dîn" Ingkang apilenggib ing Nagari Cirebon, Kanoman ing Dalem kaprabonan (Muhaimin 1995).

The second tradition attributed to Shaykh Abdul Muhyi of Safarwadi is more popular, at least in West Java, than the Cirebon tradition. This is a clear indication that Pamijahan was an important place in Java for the transmission of the Shattanriyyah. This present study focuses on the Pamijahan branch.

\section{Shaykh Abdul Muhyi}

A number manuscripts, local narratives, and Dutch reports (Haan 1910) provide convincing evidence of Abdul Muhyi's role in spreading Shattâriyyah in West Java. However the sources are not reliable on when and how exactly he learned the Shațâriyyah method in Aceh and Mecca, on when he returned to Gresik, and why he fled from there to West Java.

Rinkes (1909) is the first Western scholar to concern himself with the Shattâriyyah in Java. In 1909, while finishing his dissertation on 'Abd al-Raûf of Singkel, the prominent propagator of Shattâriyyah in Indonesia, he travelled to Java. His mission was to trace the Shattâriyyah Order and the nature of the sacred sites associated to the Wali Sanga (the Nine (Muslim) Saints of Java). The journey resulted in a book entitled The Nine Saints of Java. Even though he faced some difficulties in ascertaining certain historical data, his book does provide insights into the concept of the Wali Sanga in contemporary Java. However, in traditional Javanese historiography, Shaykh Abdul Muhyi is never identified as part of the Wali Sanga network for he lived about one century after the Nine Saints of Java had carried out their propagation of Islam. It is curious then that Rinkes's book opens with a description of the tomb of Shaykh Abdul Muhyi, the founder of the Shattâriyyah in West Java. Unfortunately, Rinkes gives us no clue why he put the episode of Shaykh Abdul Muhyi in the first 
chapter. In his further failure to provide clues about when and how the Shattâriyyah came to Pamijahan, Rinkes overlooks one of the most important aspects of any account of the order's relationship to its shrines.

There are few written sources referring to the existence of Shaykh Abdul Muhyi. The oldest manuscript found in Pamijahan only states his genealogy. There is no dating associated to him in this chronicle. Kraus (1995), the only contemporary scholar to pay attention to the historical figure of Abdul Muhyi tries to examine the existence of the Shaykh from historical point of view. Based on his research employing Dutch sources, Kraus concludes:

The first cluster of Indonesian ulama we know about, the Wali Songo, stand between myth and history. The next group, the famous Acehnese scholars and mystic, Hamzah Fansuri, Shamsuddin of Pasai, ar-Raniri, and Abdur Ra'uf, as well as Macassarese Syekh Yusuf are historical person...Abdulmuhyi of Pamijahan somehow stood between these two groups. We knew that he was a student of Abdu Ra'uf, but we have no written evidence of his thought and we had no historical proof of his existence (Krauss, 1995:28)

Krauss relies on secondary sources in claiming that this wali must have exist during the period of 'Abd al-Raûf, Shaykh Yûsuf, and the Bupati of Sukapura. Following Krauss' argument, we still need additional sources to bring this figure down to 'earth'. In other words, as long as the original works written by Abdul Muhyi himself have not been found he still stands as half-myth and half-history. Nevertheless, Krauss speculates that the Shaykh is a figure who lived between 1640 and 1715. In support of this he refers to the Dutch sources which identify the Shaykh as a hâjj from Carrang' and friend of the famous rebel, Shaykh Yusuf. Furthermore, it is also mentioned that Shaykh Yusuf wrote a manuscript, which he dedicated to Shaykh Abdul Muhyi. Finally, Krauss cites sources from a local authority in Tasikmalaya (Sukapura) mentioning the Shaykh's existence. So from these perspectives, Shaykh Abdul Muhyi is emerges as a real man clouded by the absence of his own works. It is interesting to note that Krauss assumes that every wali like the Shaykh must have bequeathed written material. Of course, we should receive this statement with care, since various factors influence the traditions of writing in Java. In Java, a collection of manuscripts can disappear not only because of adverse political factors but also the mere climatic conditions. 
According to villagers of Pamijahan, there are external factors why original works written by their ancestor cannot be found. In the seventeenth century many kiais came home from the hâjj and were unable to set up their own lodges in urban areas. Some of them retreated to remote areas of the countryside. The colonial control of the hâjj network was very strong particularly when the Dutch troops were able to capture the northern port Sultanates of Banten and Cirebon and then most of the interior of the Priangan. Some kiais, including Shaykh Abdul Muhyi, were recognised as the supporters of rebellion. In such circumstances it is feasible that Abdul Muhyi might transmit his teaching not through written sources as did Hamzah Fansuri or Nûr al-Dîn al-Rânîrî but through practical exemplary behaviour. ${ }^{11}$ It is important to consider Abdul Muhyi's teaching method within traditional institutions such as those in which ulama and ajengan deliver their lectures in oral discourse and practical applications (Dhofier 1990). Imagining such a situation, it probably was very difficult for Abdul Muhyi to introduce his teaching in a written form, in the remote and backward setting of Pamijahan in the eighteenth century.

Another factor is that certain areas of the interior of West Java experienced long periods of war and rebellion. A great number of cultural artefacts were destroyed or taken away to other places. During the 1960s, when Islamic separatism threatened the Tasikmalaya area, for example, a number of Hindu relics and other pre Islamic artefacts were deliberately broken. Many statues in West Java lost their important identifying points of iconography such as heads or hands. One of my informants in the field recited the same stories regarding various artefacts associated with Shaykh Abdul Muhyi. According to him, in the period close to the wali's lifetime not only manuscripts, amulets, and kris were lost but also the sacred mosque containing various manuscripts related to the Shaykh was burned.

We should also consider that there were periods when Shattâriyyah teachings were probably abandoned by adherents under the pressure of the spread of other popular tariqah such as the Naqshbandiyah, Qâdariyyah, Tîjâniyyah and Idrîsiyyah. Mama Ajengan Satibi, one of the family of the Shaykh, recently explained that he had manuscripts conveying the Shaykh's teaching which he never read because he was not a follower of the Shatțâtiyyah, the very Sufi order introduced in this area by his ancestor, Shaykh Abdul Muhyi.

Written materials can decay in a short time due to the unfriendly 
tropical climate, while the method of collection and storage of mss by the villagers leaves much to be desired. Accordingly, the apparent lack of the Shaykh's owns works does not necessarily put his existence into question.

I found almost thirty manuscripts from various places in Java recognising Abdul Muhyi as one of the Shattâriyyah masters. These manuscripts have been mainly copied by his followers. According to the family of the Shaykh in Pamijahan, his pupils often made copies of mystical works after he had initiated them as disciples. Furthermore, they also put their own names in the silsilab after the master's name. This custom is consistently mentioned by Shattâriyyah manuscripts dedicated to the Shaykh. In fact, according to the villagers, a Shattâniryyah manuscript which has not supplied its silsilah in the opening is not to be recognised as genuine.

\section{The Successors}

Abd Abdul Muhyi's successors were very important in transforming Pamijahan into a centre of the Shattâriyyahin Priangan, from where the order spread to other regions in Java (silsilab anak-anaknya). Most Shattâriyyah manuscripts from Pamijahan ${ }^{12}$ agree that after Abdul Muhyi died the Shattâriyyah was spread by Abdul Muhyi's sons by his first wife ${ }^{13}$, Shaykh Haji Abdullah ing Karang desane lan ing Safarwadi Padukuhane, Sembah Dalem Bojong and Emas Paqih Ibrahim ${ }^{14}$. The latter is a very well known figure along the north coast of Java and also in Kartasura in Central Java.

\section{Paqib Ibrabim}

There is no available source in Pamijahan regarding Paqih Ibrahim's life. Babad Tanah Jawi indicates that there was a penghulu from Karang who taught Islam in Kartasura. Rinkes (1996) doubts this possibility but does not provide reasons for his doubt. However, if we trace back the silsilah of the Shattâriyyah from Central and East Java we often come across the mention of a son of Abdul Muhyi, named Paqih Ibrahim ${ }^{15}$. So far, there is strong evidence that he settled in the north coast area and there taught Shattâriyyah. Local narratives in Pamijahan also note that, unlike Abdul Muhyi's other sons, only Paqih Ibrahim is buried outside this village. During his lifetime it is possible that he made contact with Kartasura. The Shattâriyyah manuscripts from Kartasura (Leiden Cod. Or. 7486b, and Cod. Or. 7446) support this possibility. In these manuscripts Paqih Ibrahim 
delivered Shațâriyyah initiation to one Tuan Shaykh 'Abd al-Rahmân from Kartasura, who in turn taught Kiai Muar Ibnu Syahid, who in turn taught Kiai Muar Ibn Syahid or Ki Mustahal, who in turn taught Kiai Muhammad Rajudin from Salakarta Adiningrat, who taught Bagus Nasari Malang, who finally taught Perwamenggolo from Pamukan Salakarta Adiningrat. Furthermore, some manuscripts indicate that Emas Paqih Ibrahim not only had followers from his own villages and neighbouring villages but also from as far away as Cirebon and Garut. Furthermore, according to Ricklef, Paqih Ibrahim was reported to have collaborated with rebels in the court of Kartasura and then was exiled to Jakarta.

\section{Haji Abdullah}

Most manuscripts found in Pamijahan during my field work belong to the Haji Abdullah's silsilah. Through his line, the Shattâriyyah silsilah is also linked to the Penghulu of Bandung, who in turn taught Haji Abdullah bin Abdul Malik, who lived at Pulau Rusa in Trengganu, who then, taught Lebai Bidin son of Ahmad, an Acehnese (see also Al-Attas 1963, 29).

\section{Dalem Bojong}

Another of Abdul Muhyi's sons, Dalem Bojong, had followers mainly from his own village, Nagara (Sukapura), Mandala ${ }^{16}$, Bandung, and Garut. The current leader of the Shattâriyyah in this village connects his silsilab to Dalem Bojong. According to a manuscript from Pamijahan (discussed below) Dalem Bojong authorised Kiai Mas Hijaya from whom Kiai Mas Haji Abdul Daud obtained authorisation (ijaza). After that Kiai Mas Haji Abdul Daud Pamijahan taught Mas Haji Hanan, who later authorised Muhammad Akna Pamijahan. Beben Muhammad Dabas, Muhammad Akna's son, then perpetuated his family tradition of the Shattâriyyah in Pamijahan.

It is important to note here that besides these three famous sons of Abdul Muhyi who are recognised as Shattâriyyah propagators after Abdul Muhyi, there is another name which is also important. Ekadjati explains that in a manuscript found in Limus Tilu, Garut there is reported to be another son who propagated Shațâriyyah, a certain Kiayi Haji Abdul Muhyidin. According to this manuscript he is recognised as Abdul Muhyi's son ("Karangan Kyai Haji Abdul Mubyiddin, kang Anak Kyai Haji 'Abd al-Mubyi, ing karang desane. Walabu allam."). The appearance of this name contradicts informa- 
tion in Rinkes' and local narratives. Neither of these sources mentions Kiayi Haji Abdul Muhyidin as Abdul Muhyi's son. If this name is correct, then his name should be 'Kiayi Haji Mas Nida (Muhammad) Abdul Muhyi or Kiahi Bagus Muhammad Abdul Muhyidin, who, according to the Pamijahan manuscripts, is the son of Dalem Bojong and grandson of Shaykh Abdul Muhyi. Local manuscripts also state:

... lan iya iku amuruk maring Shaykh Hajji Abdul Muhyi / ing karang desane lan ing Safarwadi Padukuhane lan / iya iku amuruk iya maring Kang Putra Shaykh Hajji 'Abd / al-lah hing Karang desane lan ing safarwadi Padukuhane lan / iya iku amuruk ia maring Kang Putu Kiahi mas Nida Muhammad Abdul Muhyi ing Karang Desane lan ing Safarwadi Padukuhane ...

... and he taught Shaykh Hajji Abdul Muhyi/ in the village of Safarwadi, Karang, and he in turn taught his son, Shaykh Hajji Abd/ al-lah in the village of Safarwadi, Karang and/ he in turn taught Abdul Muhyi's grandson, Kiahi Mas Nida Muhammad Abdul Muhyi in the village of Safarwadi, karang and in Safarwadi...

\section{Beben Mubammad Dabas}

Beben Muhammad Dabas is the current leader of the Shattâriyyah in Pamijahan. He derived his silsilah Shattâriyyah from his father, Haji Muhammad Akna, who was known by other villagers as an individual who practised the Shațtâriyyah. He told me, "My father, Muhammad Akna, died in 1982. He said to me that I have to carry on the Shațâriyyah in this village." Before he was initiated by his father, he spent time in a pesantren in Pekalongan, North Java. His family was surprised by his ability to learn and lead torikob because they knew that Beben had been naughty as a child. After spending time in the pesantren, he returned to Pamijahan and established Torikob Shațâriyyah on 4 April 1991.

Some prominent members of Shaykh Abdul Muhyi's family state that Beben Muhammad Dabas was too young to be a leader of the Shattâriyyah in the village. Ajengan Endang's opinion probably represents such attitudes. He explains that it is difficult to obtain an ijâzah in the Shattâriyyah because it is the wali's order. Only a few people in contemporary West Java are able to practice the Shattâriyyah properly. Beben himself seems to reject such criticism. In his view, as long as one has true niat or intention to learn the Shatțâriyyah, one can receive the ijâzah from a master. It does not mater that he is still young. Such an opinion is an example of interpersonal dynamics in the sacred sites, which are controlled by the family of the saint.

Dabas' silsilah, which he obtained from his father, is a legitimate 
one not only for tarîah requirements but also from the government's point of view. By using a hereditary privilege, he is connected to his father, once recognised by other villagers as the foremost figure to practise the Shattâriyyah. Furthermore, he also uses a legitimate manuscript, which has apparently been collected by his family. In this manuscript, he has added his own name in the silsilah of Torikoh Shattâriyyah by initiation (bai'ab) after he learned and obtained the ijâzah from Ajengan Sukawangi Singaparna ${ }^{17}$. However, it should be carefully noted that the way Beben Muhammad Dabas put his name after his father's is ambiguous. Traditionally, he should list his name after Ajengan Sukawangi, who initiated him into the Shatțâriyyah practice. However, Dabas argues that since his father bequeathed him the Shattâriyyah, it is by virtue of this fact that it is legitimate for him to continue the tradition. Furthermore, according to Dabas, he had made an oath or talqien Shattâriyyah to a murshid in the traditional way and he has listed his torikob officially in the Pakem as the third source of legitimation.

Dabas' mystical association is also affirmed by authorities in Tasikmalaya as a political matter. It is somewhat odd to Sufism that the tariqah is listed in kebatinan affairs. In a certificate given by the Sekretariat Umum Team Pakem, Beben Muhammad Dabas is recognised as the leader (pimpinan). The main objective of his organization, which is written on this certificate, is to develop Islamic instruction through the teaching of taubid in order to gain prosperity in this world and the hereafter ("Mengembangkan ajaran Islam melalui ajaran Taubid demi tercapainya Bahagia dunia dan akhirat"). It is also reported that the source of torikob is "the teaching of the torikoh which is based on al-Qurân, Hadîth, Ijmâ' ulama and Qiyâs"- all orthodox principles. But the most important point regarding the silsilah can be seen in point six of the certificate, which confirms the history of the orders. The brief history of the Order (Sejarah singkat timbul organisasi ke-agamaan/Aliran) goes as follows:

"Sejarah singkatnya, bahwa saya menerima ajaran torikoh ini dari ayahanda bernama Muhammad Akna dan Beliau menerima ajaran ini dari Mas H. Hanan ke-29. Beliau dari K Mas H. Abdul Daud ke-28 $8^{18}$. Beliau dari K. Mas Hijaya ke27. Beliau dari Shaykh Abdulloh dan Bagus Muhammad Abdul Muhyidin Pamijahan ke-26. Beliau dari Shaykh Haji Abdul Muhyi Saparwadi Pamijahan ke-25. Dari Shaykh Hamzah Pansuri Singgil ke-24. Dari Shaykh Abdur Rouf ke23. Dari Shaykh Ahmad bin Muhammad Madinah (Shaykh Qossim) ke-22. Dari Shaykh Abi Muwahib Abdullah Ahmad ke-21. Dari Shaykh Sibgatullah ke-20, 
Dari Shaykh Wajîhudin al-Alnawi ke-19. Dari Shaykh Muhammad Gaos dan putra Khotimudin ke-18. Dari Shaykh Husuri ke-17. Dari Shaykh Hidayatulloh Sarmat ke-16. Dari Shaykh qodi Satori ke-15. Dari Shaykh Hidayatulloh Sarmat ke-16. Dari Shaykh Qodi Satori ke-15. Dari Shaykh Abdulloh Sathori ke-14. Dari Shaykh A'rif ke-13. Dari Shaykh Muhammad Asik ke-12. Dari Shaykh Maula Nahari ke11. Dari Shaykh Hasana Harqoni ke-10. Dari Shaykh Rumli Tari tusi ke-9. Dari Shaykh Qutub Mudofar ke-8. Dari Shaykh Arobi yazidi istri ke-7. Dari Shaykh Muhammad Magribi ke-6. Dari Shaykh Abdi Yazid Bustami ke-5. Dari ShaykhJafarus Sodiq ke-4. Dari Shaykh Imam Muhammad Bakir ke-3. Dari Shaykh Jenal Abidin ke-2. Dari Sayidina Hasan Husen R.A. dan dari Sayidina Ali bin Abi Tholib K.W. beliau dari K. Nabi Muhammad S.A.W.

Dabas' blood relationship with the wali through his father, his silsilah, and the government approval to his association act as significant proof to some villagers that Beben Muhammad Dabas is the legitimate leader of the Shațâriyyah.

\section{Conclusion}

The Shattâriyyah emerged as the part of an expansion of Sufi orders in the $17^{\text {th }}$ century. Sufi order in Indonesia should have an accepted silsilah which excludes all heterodox figures from the line of transmission. This line not only refers to al-Bistami but also to 'Ali and the Prophet.

A dynamic network of various important orders influenced this period. Whereas Johns (1975: 34) and Drewes (1986: 57) state that Indian Islam is recognised as a main influence in this time; Azra (Azra 1992) stresses a different avenue: that the $17^{\text {th }}$ century scholarly networks, including that of the Shatțanriyyah were derived directly from Arabia. The order gained followers not only from Sumatra but also Java. Shaykh Abdul Muhyi emerges as an important figure in Java after 'Abd al-Raûf al-Singkel. It is through his silsilab that followers from various places in Central and Eastern Java derive their intellectual chain.

By considering the historical facts behind the figure, which are listed in the silsilah, we will also find an illustration regarding the tension between Sufis and the authorities. Historical and anthropological studies on the emergence and decline of Sufi orders from Morocco to Indonesia also reveal this phenomenon. The Sufi orders provide their communities with acceptable popular beliefs in order to cope with social problems. As consequence, the shaykhs' political influence is proportionate to the number of their followers. The authoritative figure of the Shaykh sometimes is recognised not only as 
a potential legitimation but also as a threat to a government.

Furthermore, the tarîqah Shattâriyyah, like any other tarîqah, experienced fluctuations in its development. In Pamijahan and in other parts of Java, Shattâriyyah followers were overwhelmed by other tarîgah appearing later. These fluctuations are associated with international influences absorbed by pilgrims on the hâjj. The silsilah of the Shattâriyyah in Pamijahan constitutes a true silsilah, however. Beben Muhammad Dabas, claims that his Shattâriyyah, still survives in the village. Nevertheless, the contemporary Pamijahanese see the genealogy of the taríqah not only in terms of sufism, but also as a legitimation of all the families in Pamijahan who claim to be related to Abdul Muhyi. In this case, the silsilah of the Shattâriyyah is also recognised as a source of identity for some villagers. All Pamijahanese claims that they have inherited the characteristics of Abdul Muhyi's Sufism. The silsilah is not only used to legitimate the mystical group but also serves as an embedded identity for all Pamijahanese. The various silsilah also come forth as a major means of continuing the cult of the wali. People believe that by reciting a particular formulaic chant, which is dedicated to the names listed in silsilah, they will obtain barakah.

This is only a simple example of the spreading of this tradition, which locate Pamijahan as an important episode in the story of Neosufism in Indonesia particularly in West Java. Furthermore, it is also another simple example that describing the genealogy of Sufi Order can reveal the scholarly network behind the phenomena as has been intensively used by Azra (1995) in his research. 


\section{Endnotes}

1. According to Rinkes 'pamijahan' should be derived from the word 'tree' since the name of villages in Java are often associated with the name of a tree. He also states that "nothing to do with Sapar, 2nd month of the Muslim year (181)

2. In Sundanese, the word mijah is also associated with moving and growing.

3. 'Ajengan' is a synonym of Muslim scholar. In Central and East Java, it is called kiai.

4. Nahdatul Ulama means "Renaissance of Religious Scholar" founded in 1926 by Hasyim Asy'ari. It is known as the group of tradisionalists who use traditional curriculums in their traditional boarding school.

5. Muhammadiyah is often called as the reformist or the modernist due to its curriculum in their teaching which combine religious teaching and social activities.

6. Persatuan Islam or Persis is probably the most conservatives group in Indonesia. They promote Islamic value in the spirit of back to the scriptures in literary sense.

7. This is a Sufi Order which combine two doctrines of Qâdiriah which founded in 1166 by 'Abd al-Qâdir al-Jîlânî and Naqshbandiyah which is founded by Bahâ' alDîn al-Naqshabandî in 1389.

8. Idrîsiyyah is the variant of Sanûsiyah Order. Sanûnisyah is the famous Order in North Africa founded by Sayyid Muhammad 'Alî al-Sanûsî al-Mujâhirî al-Hasanî al-Idrîsî in 22 December 1787. In Tasikmalaya, Idrîsiyah Order was founded by K.H Abdul Fatah in 1932. In North Africa, Idrîsiyyah was very progressive Order. They provided Bedouin (the locals) not only mystical teaching but also identity and ideology to faced colonial administrators. In Indonesia, the name of Sanûssiyah was changed into Idrîsiyyah to cover their international influences.

9. For comprehensive study about the transmission, see Azra 1994.

10. See Azra, 1994, especially chapter iv.

11. Dhofiers also mentions that the prestige of kiai and its pesantren is shown by the number of books read and to whom they had studied (1990:21)

12. Full description can be found in $p$.

13. Oral narratives mention that Muhyi had four wives these are Sembah Ayu Bakta, Sembah Ayu Salamah, Sembah Ayu Fatimah, and Sembah Ayu Winangun. From the first wife Muhyi had four sons these are Dalem Bojong, Midia Kusumah, Syekh Abdullah, and Fakih Ibrahim. See also Rinkes (1919) pp. 5-6.

14. D.A. Rinkes (1909) "De heiligen van Java I", TBG, 52, pp. 556-589; Bagus anom, alias Mas Pekik(h) Ibrahim

15. Emas Paqih Ibrahim

16. This is a historical place where Shaykh Yusuf mentions his friend, Shaykh Abd al-Muhyî in his manuscripts. Furthermore, this placed was also used by Shaykh Yusuf as the last refugee when he conducted to the Dutch.

17. Singaparna is around $20 \mathrm{~km}$ to the western Tasikmalaya city or $60 \mathrm{~km}$ from Pamijahan. Singaparna is part of the district of Tasikmalaya.

18. This silsilah is slightly different to silsilah written in manuscript (D). Manuscripts $\mathrm{D}$ linked his father silsila to Dalem Bojong but in this formal document he draws his father silsila to Shaykh Abdullah and Bagus Muhammad Muhyidin. 


\section{Bibliography}

Alisjahbana, S. T., ed. 1961. Puisi Lama. Jakarta: Pustaka Rakyat

Azra, A. 1995. Jaringan Ulama Timur Tengah dan Kepulauan Nusantara Abad XVII dan XVIII. Bandung: Mizan

Christomy, T. 1986. Hill al-Zill Suntingan naskah dan Pengkajian Tema. S1 thesis, Univesitas Indonesia, Jakarta

Dhofier, Z. 1980. The Pesantren Tradition: A Study of the Role of the Kyai in the Maintenance of the Traditional Ideology of Islam in Java. Phd. thesis, Australian National University, Canberra

, 1982. Tradisi Pesantren: Studi tentang Pandangan Hidup Kyai. Jakarta: Lembaga Penelitian, Pendidikan dan Penerangan Ekonomi dan Sosial

Drewes, G. W. J. B., L.F. 1986. The Poems of Hamzah Fansuri. Dodrecht Holland: Foris

Haan, F. d. 1910-12. de Preanger-Regenschappen onder bet Nederlandsch bestuur tot 1811. Batavia: Bataviaasch Genootschap van Kunsten en Wetenschappen [gedrukt ter Boekdrukkerij G.Kolff]

Hurgronje, C. S. 1883. De beteekenis van den Islam voor zijne belijders in Oost-Indie

—, 1929. 'Abd al-Aziez Bin 'Abd ar-Rahmaan Aal Sa'oed koning van den Hidjaaz en van Nedjd en onderhoorigheden

—, 1986. Makkah a bundred years ago, or, C. Snouck Hurgronje's

Johns, A. H. A. 1955. "Dakaik al-Huruf by 'Abd al-Raûf of Singkel. Journal of the Royal Asiatic Society :55-73

—, 1957. "Malay Sufism". Journal of Malay Branch of Royal Asiatic Society 178

_ 1965. The Gift Addressed to the Spirit of the Prophet. Canberra: Centre of Oriental Studies, A.N.U

_ 1975. "Islam in Southeast Asia: reflections and New Directions". Indonesia $19: 35-55$

Kraus, W. 1995. "An Enigmatic Saint: Shyekh Abdulmuhyi of Pamijahan (16401715)". Indonesian Circle

Muhaimin, A. G. 1995. The Islamic Traditions of Cirebon: Ibadat and Adat among Javanese Muslims, Australian National University, Canberra

Naguib al-Attas, s. 1970. The Mysticism of Hamzah Fansuri. Kualalumpur: Univ. of Malaya Press,

Rinkes, D. A. 1909. Abdoerraoef van Singkel, Leiden University, Leiden

_, 1910. "De Heiligen van Java". Tijdshrif voor Indische Taal, Land, en Volkenkunde $53: 435-581$

Rizvi, S. A. A. 1983. History of Sufism in India. India: Muhishram Manoharial

Santrie, A. M. 1987. "Martabat Tujuh Karya Shaikh Abdul Muhyi". In Martabat Tujuh Karya Shaikh Abdul Mubyi. Bandung: Mizan

Schimmel, A. 1981. Mystical Dimensions of Islams. Chapel Hill: The Univesity of North Carolina Press

Suratno, Chamamah. 1982. Memahami Karya-Karya Nurruddin Arraniri. In Memahami Karya-Karya Nurruddin Arraniri. Jakarta: Pusat Pembinaan dan Pengembangan Bahasa Departemen Pendidikan dan Kebudayaan

Voorhoeve, P. 1955. "Lisjt der Geschriften van al-Rânîrî en apparatus Criticus bij de Tekst van Twee Verhandelinge". BKO 111

_, 1961. "Supplement of de Lisjt der Geshriften van al-Rânîrî". BKI 117

Tommy Christomy is a PhD. Candidate at the Southeast Asian Centre FAS, Australian National University, Canberra. 


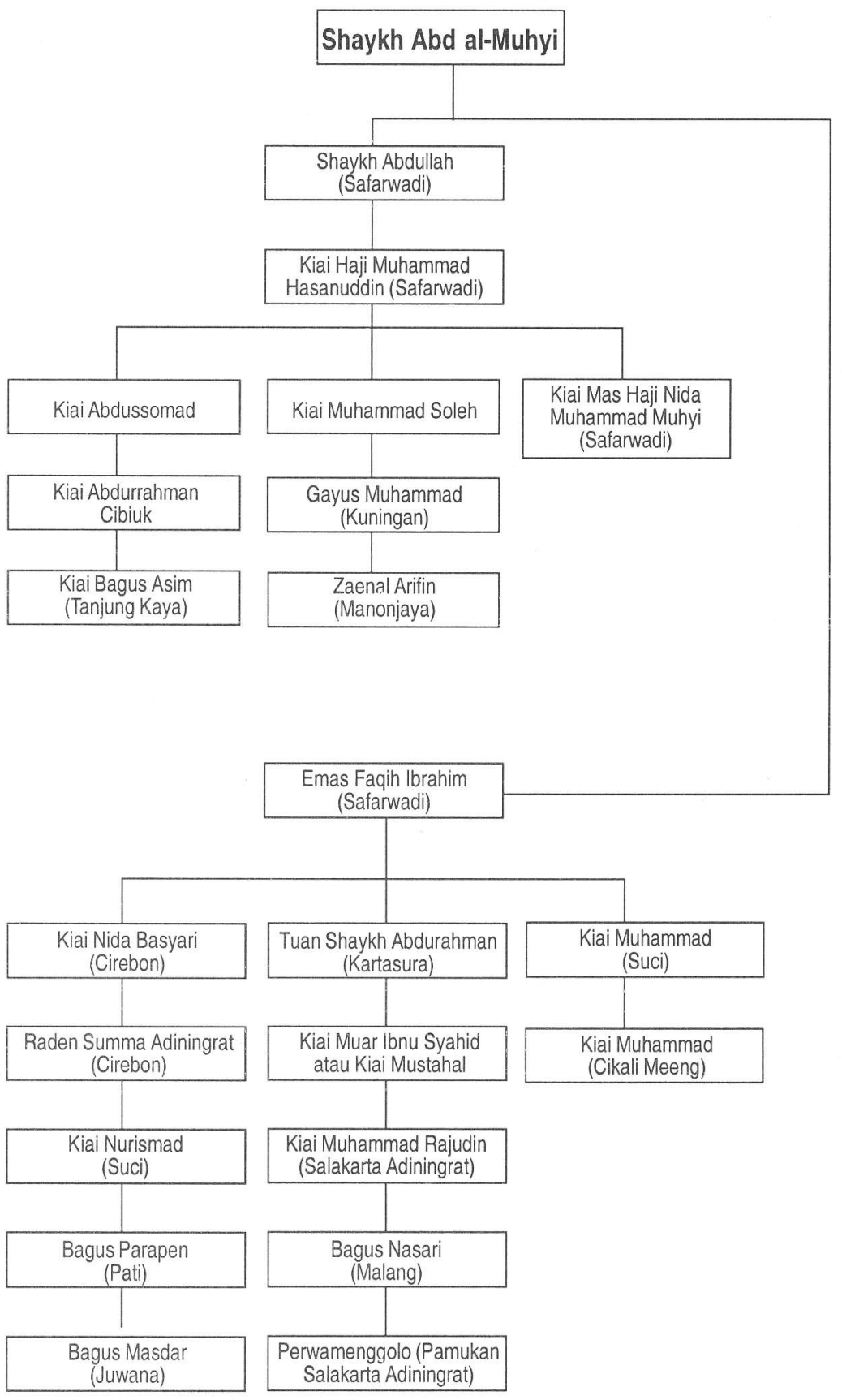




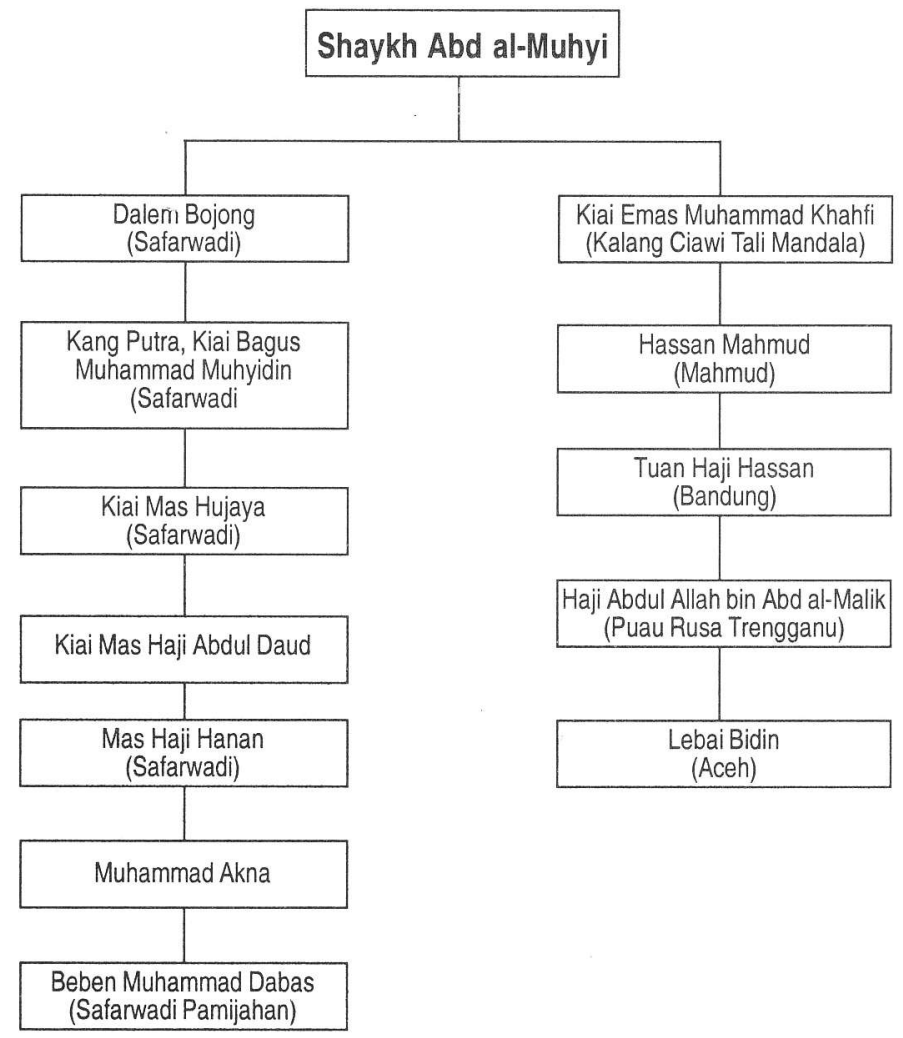

